University of Wollongong

Research Online

Faculty of Business - Papers (Archive)

Faculty of Business and Law

2013

Institution building and variation in the formation of the Australian wool market

David Merrett

University of Wollongong

Simon Ville

University of Wollongong, sville@uow.edu.au

Follow this and additional works at: https://ro.uow.edu.au/buspapers

Part of the Business Commons

Research Online is the open access institutional repository for the University of Wollongong. For further information contact the UOW Library: research-pubs@uow.edu.au 


\title{
Institution building and variation in the formation of the Australian wool market
}

\begin{abstract}
The relocation of the wool market from London to the major Australian port cities from the late nineteenth century required the formation of an institution to govern the auction business, namely the wool brokers' association. Regional variations, among Sydney, Melbourne, and Brisbane, occurred in the structure and effectiveness of the institution despite each regional association having been formed around the same time, for the same purpose, and with an overlap of participating firms. We draw on institution theory to guide our account and find that the impact of legacy factors and differences in market conditions explain the regional variations.
\end{abstract}

\section{Keywords}

era2015, formation, australian, wool, building, market, institution, variation

Disciplines

Business

\section{Publication Details}

Merrett, D. \& Ville, S. (2013). Institution building and variation in the formation of the Australian wool market. Australian Economic History Review: an Asia-Pacific journal of economic, business and social history, 53 (2), 146-166. 


\title{
Institution Building and Variation in the formation of the Australian Wool Market
}

David Merrett, University of Melbourne

Simon Ville, University of Wollongong

\begin{abstract}
The relocation of the wool market from London to the major Australian port cities from the late nineteenth century required the formation of an institution to govern the auction business, namely the woolbrokers’ association. Regional variations, among Sydney, Melbourne and Brisbane, occurred in the structure and effectiveness of the institution despite each regional association having been formed around the same time, for the same purpose, and with an overlap of participating firms. We draw on institution theory to guide our account and find that the impact of legacy factors and differences in market conditions explain the regional variations.
\end{abstract}

Key Words: wool markets; institutions; industry associations;

JEL Categories: N57; N87; L44 


\section{INTRODUCTION}

The global supply chain in the world's woollen textile industry underwent two significant changes in the second half of the nineteenth century. Raw wool came increasingly from the southern hemisphere where Australia emerged as the world's foremost producer of apparel wool. Then between 1890 and 1910 the point of sale for most Australian wool shifted from London to auctions conducted across the main Australian port cities prior to export. Our study concerns the critical role of a new regionally-based institution, the wool brokers' association, in this process.

A critical element has been overlooked in earlier explanations of the transfer of the wool market to Australian cities ${ }^{1}$, the creation of an effective institutional framework to support the marketing of wool. This paper focuses on the three principal auction markets, of Sydney, Melbourne and Brisbane, which sold more than 70 per cent of Australia’s wool from the early 'nineties until 1909. ${ }^{2}$ Within each selling centre a number of firms, which simultaneously had competed to provide other types of services to wool growers, now formed associations in the 1890s whose objectives were to conduct sales through a single auction room, to charge a common fee, and to restrict non-price competition for custom. ${ }^{3}$ A study of these events permits us to observe the creation of an industry-specific institution, the woolbrokers' association, at roughly the same time but in different geographic settings. Rich archival records enable us to explore the motivation for the establishment of the associations and to observe the interplay between the resulting organisations and their members. We discover variations in this institution and its effectiveness from city to city. We argue that participation in, and commitment to, each of the three institutional forms was dependent on localized external forces. The study is further nuanced, as each regional institution responded to the structure and performance of the others. Over time, the nature of coordination between them became as pressing as the need for coordination within each one. Our story ends in 1909 when the association in Sydney, which had collapsed in 1900, resumes and as the three associations begin discussions to establish a national body, a feat accomplished in 1918 with

\footnotetext{
${ }^{1}$ Barnard, Australian Wool Market; Ville, Relocation of international wool market, pp.7395.

2 Bureau of Agricultural Economics, Statistical Handbook, p. 36. Adelaide was also a major wool auction centre but lost ground to the other three in this period and fell behind Brisbane before World War One.

${ }^{3}$ Merrett and Ville. Industry associations and non-competitive behavior, pp. 510-28.
} 
the formation of the Federated Wool Selling Brokers of Australia, the precursor to the National Council of Wool Selling Brokers of Australia a year later. ${ }^{4}$

The paper begins by arguing that the growth of sales in the local wool market was contingent on having an effective institutional framework. We then draw on an element of institution theory ${ }^{5}$ to argue that the wool brokers' associations were a form of institution, and one situated towards the regulatory end of a regulative, normative and cultural-cognitive continuum as described by Scott. ${ }^{6}$ Insights from institution theory frame the questions driving the paper, sharpen our thinking about concepts, and offer prompts about how we interpret our data.

In the third section of the paper we use the archival records of the three associations to track their emergence and evolution. We find that all were initially designed as regulatory institutions that sought to garner cooperative behaviour among rival firms through a formal set of rules with extensive monitoring mechanisms and punishments for non-compliance. However, each adopted different sets of rules. We show how differences in the constitutional framework of each association reveal the extent of the struggle to achieve compliance and cooperation. Moreover, we find marked dissimilarities in these outcomes between associations. Cooperative impulses were far stronger in Melbourne and Brisbane than in Sydney where that association proved less effective in constraining the behaviour of member firms.

The fourth section explores the reasons for the divergence in institutional form and the wide gap in its effectiveness between cities. We shift focus to the challenges facing firms operating within each of the three market places. The structure of the local 'industries', particularly the number and type of participating firms, and the supply of wool available for sale play a key part in our explanation of the differences.

We conclude by observing that both weak and strong institutional forms were capable of underpinning the operation of the central auction system. A coordinated series of wool sales operated in Sydney despite low levels of trust between association members throughout the 1890s and throughout the Association's period of inactivity after 1900. Moreover, the Sydney

\footnotetext{
${ }^{4}$ George L Aitken, Presidential Address, National Council of Wool Selling Brokers of Australia, 17 August 1921, 106/121, 5/1, Box 24, University of Melbourne Archive (hereafter UMA).

${ }^{5}$ For an overview of the field see Greenwood, et. al., SAGE Handbook.

6 Scott, Institutions and Organizations.
} 
wool sales were increasingly coordinated with those in Melbourne and Brisbane. We return to the institution theory literature to provide an explanation of this phenomenon.

\section{REQUIRING A NEW INSTITUTION}

Prior to the creation of a central auction system in the early 1890s, Australian wool had reached world markets in a variety of ways. For the most part, local stock and station agents and banks provided consignment services to grower clients. At the margin, some firms acted as merchants buying wool directly from growers and/or at auction in Sydney and Melbourne. $^{7}$

An initially fragmented Australian auction system was not an effective substitute in the eyes of foreign buyers to the dominant practice of consignment to auction in London up to the 1880s for a number of reasons. Buyers coming to Australia faced higher costs in collecting information about multiple auction service providers, each with small offerings, who ran conflicting sales schedules, operated with different levels of charges, had idiosyncratic sampling procedures, and who had non-standard sales contracts and arbitration procedures. Buyers also faced high costs in ascertaining the quality and yield of wool, as poor classing in many shearing sheds and unscrupulous behaviour by some growers compromised their ability to ascertain the quality and weight of wool purchased.

These problems were gradually resolved by the establishment of a central auction system which coordinated and standardized the auction services provided by firms operating in Australia's major ports. It also offered high payoffs to broking firms because wool marketing had high fixed costs in terms of warehouse assets. Collective action, if successful, would attract more buyers and allow the realization of economies of scale in conducting the auction such as a shared salesroom, sale catalogue, and promotional costs. Moreover, participating firms could exploit their collective market power by raising prices and limiting non-price competition to create rents. ${ }^{8}$

The sale of wool shifted from London to Australia after the establishment of a central auction system with three-quarters of exports having been sold locally in the first decade of the

\footnotetext{
${ }^{7}$ Barnard, Australian Wool Market, pp. 149-55; Ville, Rural Entrepreneurs Table 6.1, 122-23 and Table 6.2, p. 126.

${ }^{8}$ Merrett and Ville, Industry associations and non-competitive behaviour, pp. 511-12
} 
twentieth century. ${ }^{9}$ Buyers negotiated with the newly formed wool selling brokers' associations about the conduct of the auction system, including the movement of wool into and out of the stores, the weighing and sampling of bales before auction, the terms of payment and dispute resolution all of which reduced uncertainty.

The central auction system in each of the port cities was therefore organized by wool selling brokers' associations. These bodies were registered as organizations under extant company law. However, in purpose and form they were a type of institution. They were designed as vehicles for co-ordination amongst firms who anticipated that participation would bring greater financial rewards than operating independently. These associations were not purposive wealth maximizing organizations in their own right. They were cost centres. The associations did not collect the revenue streams associated with wool selling. Contracts were signed between the growers and the brokers, and the buyers and the brokers, payment was made by clients to the individual broking firms not to the association. Associations had limited physical resources, initially renting an auction room, and their operation relied on the services of a secretary and a handful of members of the participating broking firms serving in a part-time and honorary capacity. They were accompanied by the emergence of associational behaviour among both growers and buyers with the consequence that much of the communication and many of the decisions about the development of the wool market were taken amongst a web of interacting associations. ${ }^{10}$

What type of institution were the wool broking associations? Institutional theorists such as North argue that institutions exist to reduce uncertainty by constraining behaviours. ${ }^{11}$ In Scott's schema, this end can be achieved by multiple routes. There are three 'pillars', around which institutions can be formed - regulatory which is rules-based, normative in which effectiveness rests on shared values and norms, and cultural-cognitive where 'shared conceptions ... constitute the nature of social reality and the frames through which meaning is made'. ${ }^{12}$ Following the lexicon of the field, each pillar has its own mix of elements including the basis of compliance and the basis of legitimacy, and 'carriers' such as symbolic or relational systems, routines and artefacts, which shape how the institution works. To complicate matters, institutions can be supported by a combination of pillars and their

\footnotetext{
9 Ville, Rural Entrepreneurs, Table 6.2, p. 126.

${ }^{10}$ Merrett and Ville. Industry associations and non-competitive behavior variously discusses the grower and buyer associations.

${ }^{11}$ North, Institutions, Institutional Change, p. 3.

${ }^{12}$ Scott, Institutions and Organizations, p. 57.
} 
associated compliance mechanisms and carriers. ${ }^{13}$ Following this schema, the wool brokers' associations were primarily regulatory institutions. They were established by institutional entrepreneurs in anticipation of commercial gain, actors whose behaviour was rational and deliberative. The logic for this action was 'instrumental' and those joining did so for 'expedience'. This institution employed rules and regulations whose effect was to achieve compliance via coercion. $^{14}$

The overview by Scott provides a complex and nuanced picture of the construction of institutions and the relationship between the three pillars ${ }^{15}$. The pillars typology is flexible in two directions. First, a regulatory institution can also have elements of normative and cultural-cognitive foundations, both of which rely on the strength of social obligations and shared understandings. Second, the mechanisms or 'carriers' which provide support for an institution can moderate its nature. For instance, a regulative institution such as a wool brokers' association, which at the point of its establishment relies almost exclusively on written rules and regulations, can construct a wider base of strength as it operates. Routines, standard operating procedures to do with the movement of wool though the wool stores, weighing, cataloguing and so on, and the presence of physical artefacts such as the auction room and wool stores, reinforce adherence and compliance to the aims of the institution. Time matters because it facilitates experimentation and adaptation. We will argue below that the differences between the formal constitutional governance of the institutions between cities, and the breakdown of the formal association in Sydney, mattered less than it might have because of the evolution of multiple pillars, a subtle shift towards normative and cultural-cognitive pillars, and the evolution of standardized custom and practice within and between associations. ${ }^{16}$

\section{INSTITUTIONAL GOVERNANCE AND EFFECTIVENESS}

\footnotetext{
${ }^{13}$ Scott, Institutions and Organizations, Table 3.1 and 4.1, p. 51 and 79.

${ }^{14}$ Scott, Institutions and Organizations, Table 3.1, p. 51.

${ }^{15}$ Scott, Institutions and Organizations, Ch. 3.

${ }^{16}$ There is an evolving literature of the history of industry and trade associations but we have found none that explicitly addresses Scott's three-pillar typology. Our study is also valuable in looking at a set of firms who cooperate in some areas of their business but compete in others. Recent contributions to the trade association literature, but involving industrial districts with far larger numbers of members, include Popp, 'An indissoluble destiny'; Carnevali, 'Crooks, thieves and receivers'; Carnevali, 'Social Capital and Trade Associations.
} 
Where did the institutions come from? Sydney's association, the Sydney Wool and Produce Salesman's Association, appeared first in $1889 .{ }^{17}$ The name was changed to the Sydney Wool-Selling Brokers' Association in September 1892 when it commenced a central auction. ${ }^{18}$ Melbourne followed almost immediately in March 1890 with the Melbourne Woolbrokers' Association ${ }^{19}$ and Brisbane's Wool Selling Brokers' Association started in 1897 [Hereafter SWBA, MWA and BWSBA]. ${ }^{20}$ All had built on earlier foundations. Stock and station agents, many of whom became wool brokers, had previously developed cooperative arrangements concerning auctions among local pastoralists of other farm produce and livestock, the latter involving sharing common facilities such as sale yards and coordinated sale rosters and the setting of uniform fees. In general, the associations included all of the major wool brokers although sometimes a cooperative operated independently. We will also see that several Sydney brokers temporarily resigned their membership as cooperation eroded for a while at that centre.

These leading stock and station agents were the institutional entrepreneurs who recognised that the wool auction was shifting to Australia and needed a new set of local institutions to function effectively. Firms like Goldsbrough Mort [hereafter GM], that were Australian based from the beginning, saw this as a good opportunity to build their businesses. Informal understandings were giving way to more elaborate arrangements among the chief firms at each major port. For instance, when a group of firms formed the Brisbane Stock and Station Agents Association on the $10^{\text {th }}$ of December 1894 this body had a formal constitution and comprehensive set of market rules. ${ }^{21}$ The constitutions of the new wool brokers' associations' were frequently revised and expanded over the next 20 years in a response to the perceived need to constrain the behaviours of their members and to deal with the greater complexity of the processes involved in marketing wool.

\footnotetext{
${ }^{17}$ For Sydney see Copy of Agreement, 6 August, 1889, New Zealand Loan \& Mercantile Company, (hereafter NZLM\&A), 110/4/313, Noel Butlin Archive Centre (hereafter NBAC).

${ }^{18}$ Sydney Morning Herald, Opening of New Wool Exchange, p. 6.

${ }^{19}$ Merrett, Morgan and Ville, Industry associations as facilitators, p. 783.

${ }^{20}$ BWSBA, OMA 1767/2 Minutes 15 April 1898, John Oxley Library (hereafter JOL). Other regional associations included the Adelaide Woolbrokers Association (1894), Launceston Woolbrokers Association (1904). Most states had only one selling centre until the middle of the nineteenth century. In Victoria the Geelong Woolbrokers Association (1901) was much smaller than Melbourne consisting of local firms and a major one, Dalgety.

${ }^{21}$ Brisbane Stock and Station Agents Association, OMA/1767/1 Minutes 10 April 1894, JOL.
} 
Table 1 around here

Table 1 is an attempt to capture the formal nature of the institutions in 1909 and to show in which respects they diverged. Their constitutions set out a governance structure that defined the obligations, rights and privileges of members. These were inclusive in that all member firms were part of the committee which, in the words of the Brisbane Association, had 'absolute control' over the 'entire management of the Association and of all its affairs'22. However, the number of votes granted to each member ranged from one each in Melbourne to multiple votes related to the sale of wool in the two northern centres, thus giving the larger firms in those markets more weight. However, on delicate matters such as fining or expelling members, all reverted to one firm, one vote. In both Melbourne and Brisbane, the chair was elected from among members at the Annual General Meeting. Sydney stood apart, placing itself in the hands of an independent outsider with extraordinary powers to investigate and punish breaches of the rules. Both Sydney and Brisbane felt it necessary to bribe members to attend committee meetings, or fine those coming late, whereas Melbourne did not.

The rules of all three associations bound their members to agreement on the nature of the work to be carried out in preparing wool for sale and delivery to the buyers, and the fees and charges determined by the association. There were minor variations in the rules regarding warehouse procedures, most of which were driven by buyers' requirements for the numbers of bales to be sampled for cross-bred and merino wools. However, pricing structures differed between centres and within centres over time. From their inception, Melbourne and Brisbane used a two-step 'receiving fee' linked to the volume of wool handled and a tiered sales commission, while Sydney switched backwards and forwards between that and a single composite fee linked to the value of wool sold. Member firms also agreed not to engage in non-price competition. Three activities were contentious: firms had offered 'rebates' to local agents to direct wool into their stores; travellers were employed to canvas business directly from growers; and firms advertised via a variety of media such as press notices of sales results, gifts and prizes at local shows.

Achieving agreement on prices and mitigating non-price competition was more easily achieved in some centres than others. Each association had a process that facilitated

${ }^{22}$ BWSBA OMA/1767/1, Rules, Clause 11, 18 October 1898, JOL. 
monitoring of the behaviour of member firms. Firms could bring accusations of a breach of the rules, such as undercutting the Association's rates or individual advertising, to the committee by lodging a complaint with the honorary secretary. The accused could defend itself against the charge and the committee would arbitrate. If it was found guilty, the miscreant would be fined, or expelled from the association. The latter was a credible threat as the firm would forfeit its joining 'contribution' of up to $£ 500$ and not be allowed access to the auction room. The impulse to bring an action was tempered by the need to post a small bond, usually $£ 5$, which would be forfeited if the accused was found innocent. The procedures by which the claims of the accuser and those accused were investigated varied significantly between centres. Sydney was the outlier. Once a serious breach had been established, the matter passed to the 'arbitrator' for adjudication. The arbitrator had the power to call witnesses and to examine the documents of the defendant. Brisbane moved some way down the same path by being able to employ the services of an external accountant to examine more complex cases.

The effectiveness of the three associations in controlling the actions of their members differed widely. In short, Melbourne and Brisbane operated without serious internal discord over many decades. ${ }^{23}$ The Sydney Association, by comparison, was so wracked by dissent throughout the 1890s that it lapsed between 1900 and 1909. Sydney brokers squabbled and 'cheated' on agreements covering fees and those limiting non-price competition to such an extent that margins and profits were lower than in Melbourne or Brisbane. For instance, Australian Mercantile Land and Finance Company [hereafter AMLF] did not expect to earn any profit from its wool broking activity when it entered the Sydney market in $1904{ }^{24}$

The paradox is that the Sydney constitution anticipated this type of behaviour, the result of low trust and wavering commitment by members, through its heavy handed rules. We suggest that these arrangements reflected a continuing lack of trust between the founding firms in the 1890s and amongst the enlarged group of firms operating in the 1900s. There may have been doubts about the impartiality of any elected chair and the possibility of fears that firms might form coalitions to lock in key positions in the Association to the detriment of others. When the Association was re-formed in 1909, the role of Arbitrator was extended from being the chair of the association to chairing all meetings of the committee, although he could delegate

\footnotetext{
${ }^{23}$ Ville and Merrett, Inter-organizational communication, pp. 171-9; Merrett, Morgan and Ville, Industry associations as facilitators, pp. 73-95.

24 Bailey, Pastoral Banking, p. 182.
} 
but only to another impartial individual. In contrast, Melbourne and Brisbane members continued to elect their chair from amongst their own number. Sydney also limited the time frame of its association, ranging between three to five years, before the contract would be renegotiated. Brisbane followed suit. However, for all its severity, Sydney's regulatory institution failed compared with those in the other cities, insofar as it proved unable to bring about cooperation.

Tables 2 \& 3 around here

\section{WHY DID INSTITUTIONS DIFFER?}

As shown in Table 2 and 3, a number of wool brokers operated in both Melbourne and Sydney, and several also had branches in Brisbane. Why did Melbourne not adopt Sydney's rules, and the late comer Brisbane simply follow what had been adopted in the southern capitals? ${ }^{25}$ Table 1 shows that the constitutions had much in common. However, the lack of trust between members in Sydney is reflected in the two outstanding differences between it and the associations in Melbourne and Brisbane, the adoption of an independent chair and a fixed time period. Even where rules converged over time as a result of conferences attended by all the associations, practice continued to differ. We will argue that localized factors generated differential levels of trust at the time of association formation and rule framing, and that these perceptions became embedded as a form of path dependency. Institutional theorists are divided about the longevity of institutional structures ${ }^{26}$. Our study suggests that the character of the institutions adapted to changing circumstances in what is from an historian's perspective quite a short time frame. Moreover, the process of adaption was multi-faceted. While the formal rules of each of the three associations were revised periodically some significant differences remained. However, the willingness to cooperate was enhanced by the strengthening of the normative and cultural-cognitive aspects of the pillars supporting the institution. Convergence occurred more rapidly on these latter two dimensions than on the formal rules.

\footnotetext{
${ }^{25}$ The Brisbane brokers obtained copies of the constitution and rules of both the Sydney and Melbourne Associations prior to drafting their own. BWSBA OMA/1767/1 Minutes. 29 August 1894 and 6 December 1894, JOL.

${ }^{26}$ Scott, Institutions and Organizations, pp. 128-32.
} 
Following the reasoning of economists and economic historians, we argue that the level of commitment by wool brokers to the formal rules of an association, and an acceptance of high levels of coercion to enforce conformity, depended on their calculations of the resultant pay offs. ${ }^{27}$ Being a member of an association offered two benefits: a greater number of sellers and buyers participating in a centralised auction; and the ability to collude at the expense of growers and buyers. The potential size of these benefits and the ability to realize them depended on the extent to which other brokers became members. The more universal the membership, the greater the likely benefit of being a member and vice versa. Moreover, brokers could continue to act as members of the association to receive one rather than both of the benefits, to seek increased throughput in the wool store or to seek higher margins by raising fees and limiting non-price competition. In either circumstance, some brokers might decide that their interests were best served by 'cheating' the association. They would weigh the likely benefits arising from gaining greater market share by breaking the rules against the costs of being punished. Brokers' decisions to so act would be influenced by the likelihood of being caught, an outcome which would depend upon the resources that the association devoted to monitoring its members’ actions.

These same set of considerations impacted on the drafting of the initial constitutions and rules. The men who negotiated the establishment of the associations had an intuitive understanding of the pay offs and the likely responses of firms operating in the industry. Expectations of commitment differed across the three regions, New South Wales, Victoria and Queensland, feeding into the three auction centres of Sydney, Melbourne and Brisbane in the 1890s. The handful of brokers in Melbourne had long cooperated through informal arrangements conducted by the Chamber of Commerce, while those in Sydney quarrelled throughout the 1880 s. $^{28}$

Melbourne had lost the title of the 'principal wool mart of Australia' to Sydney in the 1880s: sheep numbers in the colony grew rapidly, more firms were willing to trade wool, and Sydney's commercial centre and rail communications expanded rapidly. ${ }^{29}$ However, the core group of participants in Melbourne remained unchanged for decades to come. Most of these were large scale financiers to the pastoral industry, funding the acquisition of stations,

\footnotetext{
${ }^{27}$ North, Institutions, Institutional Change, p. 15.

${ }^{28}$ Barnard, Australian Wool Market, p. 110, note 13 \& pp. 154-5.

${ }^{29}$ Franklyn, Glance at Australia in 1880, p. 203.
} 
investments in flocks and equipment, and providing working capital as well as acting as brokers. ${ }^{30}$ The bundling of lending and broking services generated strong 'ties' with their customer base and the firms established strong social capital ties with one another over time ${ }^{31}$

Sydney differed in that these 'financiers' were not the dominant force in the less concentrated broking market in the 1890s or 1900s. Sydney continued to have a larger and more diverse group of selling brokers. Comparing Sydney and Melbourne in 1906, there were twice as many brokers in Sydney and the market was much less concentrated. The four largest sellers were responsible for 49 per cent of the market in Sydney but 78 per cent in Melbourne.

Calculation of Herfindahl concentration indices confirms that Melbourne was 50-100 per cent more concentrated than Sydney. ${ }^{32}$ Cooperative behavior is easier to achieve in an association where there are few and stable members. Trust is stronger, monitoring is less costly, and consensus easier to achieve.

Heterogeneity in Sydney was about business models as well as size. Three types of firms each had distinct business models. The national firms (Dalgety. New Zealand Loan \& Mercantile Agency [hereafter NZLMA], GM and AMLF) had access to long term loan facilities with which to buy farmer loyalty, the ability to shift resources between centres as required, and London offices to advise them on international market conditions. These were all valuable resources, for example, a presence in different markets enabled firms to shift resources to Brisbane and Adelaide as their share of national sales increased at the expense of Sydney and Melbourne. The larger Sydney-based houses (Winchcombe Carson; Harrison, Jones and Devlin; and John Bridge and Co) had reasonable financial backing but lacked the geographic flexibility and information flows of the former group. The smaller Sydney houses (Hill Clark and Pitt Son and Badgery) lacked all of these levers of competitive advantage and instead relied heavily upon social networks and business connections as their main sources of strength but competed with farmer cooperatives on this basis.

Why were the Sydney firms unable to cooperate? We argue that the level of uncertainty associated with falling prices and the drought might prompt participants to take a short-term view of the industry and their involvement. Paradoxically, the level of charges agreed upon at

\footnotetext{
${ }^{30}$ Butlin, Investment in Australian Economic Development, ch. 2.

${ }^{31}$ Merrett, Morgan \& Ville, Industry associations as facilitators of social capital

${ }^{32}$ Dalgety Annual Wool Review
} 
the Association's formation provided ample opportunity for 'cheating'. ${ }^{33} \mathrm{GM}$ was the undisputed market leader when the Association began yet it quickly lost share. Within four years, between 1891 and 1894, the share of the market it commanded fell from 26 to thirteen per cent. ${ }^{34}$ There were two possible drivers of such a shift. First, strong prior relationships with wool growers possessed by those stock and station agents and financiers entering the broking industry could leach share from incumbents. ${ }^{35}$ Ties between the big pastoral lenders and those in their debt were particularly powerful. Second, the impact of the long drought was uneven across and within the colonies. ${ }^{36}$ The supply of wool coming forward by the incumbents' clients was determined by the caprice of nature. However, GM's internal correspondence shows it believed that the loss of custom was directly attributable to breaking of the rules by other members of the Association. In late 1893 the Sydney manager urged his superiors to permit him to secede which they eventually did in late December. Thereafter, GM set prices independently, arguing that 'we must be allowed to conduct our internal business as suited our conditions'. ${ }^{37}$ Winchcombe Carson and John Bridge also resigned from the Association at this point, and Harrison, Jones and Devlin suggested to GM that the Association be dissolved. ${ }^{38}$

The Co-operative Wool \& Produce Company [hereafter CWP] entered the market in at the beginning of the 1896/97 selling season as a direct response to an attempt by the Sydney Association to increase charges to parity with those in Melbourne. ${ }^{39}$ CWP reached an understanding with the buyers to run parallel auctions during its first season of sales. However, the buyers boycotted CWP's sales in August of 1898 in a dispute about the imposition of a delivery charge. ${ }^{40}$ Almost immediately CWP agreed to 'recommend a large

33 By 1891 the SWSBA had diverged from the Melbourne model of charging the growers a receiving fee of $1 / 8 \mathrm{~d}$ per pound and a sales commission linked the value of wool sold. From 1891 growers using the Sydney auction room paid a composite receiving and sales commission of $3 \frac{1}{2} \%$ for sales of less than $£ 500$ pounds and $3 \%$ for larger sales. It was more difficult for Sydney firms to observe one another making private arrangements with growers to charge lower rates on sales of less than $£ 500$ than it was to catch them breaking the nonprice competition rules. NZLMA 110/4/317, SWSBA Agreement, 11 May 1891, NBAC.

${ }^{34}$ Dalgety's Annual Wool Review

${ }^{35}$ Ville,'Making connections', pp. 423-48.

${ }^{36}$ Butlin, Australian Domestic Product, Tables 1, 2 \& 3, pp. 300-05.

${ }^{37}$ GM 2/174/2, letters received Melbourne office, 2 December 1893. NBAC.

${ }^{38}$ GM 2/174/296, letter to Melbourne Manager, 3 January 1895, NBAC.

${ }^{39}$ MWA 79/178, Minutes, 14 January 1896, 21 January 1896, 24 April 1896, 17 July 1896, 11 December 1896 and 8 January 1897; MWA Annual Report, 6 March 1896, UMA.

${ }^{40}$ Sydney Morning Herald, 'The Wool Deadlock', p. 3. 
reduction in charges for adoption by the [Brokers'] Association' ${ }^{41}$ The Sydney manager for GM remarked 'we can see very well that many of the Sydney houses are in such a weak condition that they are terrified with the prospect of the Cooperative doing business at rates lower than those of the Association and thereafter ready to blindly make any modification which falls short of actually adopting the Co-operate tariff'. ${ }^{42}$ As a consequence, price cutting by members of the Association became more prevalent, and in the ensuing free-for-all the Association ceased to exist. ${ }^{43}$ Despite this retaliation, CWP's market share rose sharply, reaching ten per cent by 1902, before the newcomer's advantage quickly evaporated as the amount of wool it sold fell to six per cent of the total by 1903 and remained thereabouts until 1909. Sydney broking firms were recidivist; many took the opportunity to attract clients away from GM by breaking the Association's rules in the early 1890s and later on most retaliated against CWP.

We observe different responses to shifts in market share in the other centres. In Melbourne, GM suffered a somewhat slower reduction in the share of the market it held, from around 30 per cent in 1893 to about 20 per cent by 1903, while maintaining this figure until 1909. There is no evidence from within the records of GM to suggest that the firm believed this fall from grace was the result of cheating by its associates in the MWA. The rise of Younghusband's wool sales compared with the rest occurs from the early 1900s after GM's position has stabilized rather than in the 1890s. The MWA did not suffer from 'ruinous' competition during its formative years.

The Brisbane market grew quickly from a low base to overtake Geelong and Adelaide as the third largest wool selling centre by WWI. ${ }^{44}$ Over time, there were large swings in the share held by individual firms. Initially, Dalgety was the dominant firm with a share of nearly 60 per cent. The entry of NZLMA to selling wool in Queensland in 1904 reduced Dalgety's share by more than a third within a year. However, NZLMA's share levelled off quickly without a hint of retaliation by price cutting or non-price competition. It is possible that the great savings in overheads in Brisbane, resulting from sharing warehouse premises in a leased building, lessened the need especially amongst the smaller firms to cheat to maintain volume. The brief drop in Dalgety's market share was not threatening to the firm which was emerging

\footnotetext{
${ }^{41}$ GM, 2/28A (3) letter to London, 14 September 1898, NBAC.

${ }^{42}$ GM, 2/28A (3) letter to London 14 September 1898, NBAC.

${ }^{43}$ NZLMA, 110/4/319 letter to manager, 21 March 1900, NBAC.

${ }^{44}$ Bureau of Agriculture Economics, Statistical Handbook, Table 1, 1.
} 
as the giant of the industry, ${ }^{45}$ and NZLMA, a recent newcomer to wool broking, had sufficient resources to ride out any temporary swings in share.

Melbourne also provided fertile ground for the creation of a strong institution. Priors mattered. There was a long history of cooperation amongst the small number of firms which became members of the association. As shown in Table 2, the industry structure was relatively stable with Younghusband and Co being the only new entrant in the years immediately prior to the formation of the association. The competitive impact of this firm was muted as it reached out into the Riverina district of southern New South Wales from its base in Albury rather than competing head on for Victorian wools. ${ }^{46}$ Another three new firms entered and left within the space of a few years, Victorian Farmers Loan, National Wool Trading Co and Co-operative Wool \& Produce, ${ }^{47}$ without making much of a mark. Two of the strugglers, Union Mortgage \& Agency [hereafter UMA] and Australasian Mortgage \& Agency, were absorbed by Australian Estates and AMLF respectively in 1899 and 1904. In a relatively settled environment, the MWA's constitution underpinned collegial decision making. While members monitored the actions of their peers, transgressions were infrequent and the modest enforcement procedures were seldom used. Substantial amounts of social capital underpinned the smooth workings of the association. ${ }^{48}$

The Association in Brisbane was formed in special circumstances that favoured co-operation. Queensland wool had left the colony on consignment for sale overseas or found its way into sales rooms in Sydney and Melbourne. Four stock and station agents, Moreheads, MacTaggart Bros, UMA, and Fenwick, had formed the Brisbane Stock and Station Agents Association in December 1894 to collaborate on livestock sales. Earlier in the year 'a desultory conversation took place with reference to the establishment of wool sales, but no resolution was come to'. ${ }^{49}$ However, within a few years these same firms made a concerted effort to begin a local wool market. They needed to work cooperatively to build the necessary infrastructure. Under the energetic leadership of John Leahy, the local director of UMA and a

\footnotetext{
${ }^{45}$ Hartwell, Dalgety, typescript, chapter 9, 12-13.

46 Were's Statistical Service. Younghusband \& Co.

${ }^{47}$ The CWP, which operated in Victoria, was a separate entity to the one in New South Wales, although the firms shared some directors. Unlike its northern counterpart, the Victorian CWP cooperated with the MWA. Sydney Morning Herald, 'The wool deadlock', p. 3. The Victorian CWP was sold to Younghusband in 1901. Argus, 25 March 1901, p. 4.

${ }^{48}$ Ville and Merrett, Investing in inter-organizational; Merrett, Morgan and Ville, Industry associations as facilitators, pp.73-95.

${ }^{49}$ BWSBA, OMA 1767/1 Minutes, 9 March 1894, JOL,
} 
member of parliament ${ }^{50}$, they lobbied the colonial government on a range of matters: subsidies, relief from export taxes, and reductions in railway freights. ${ }^{51}$ The members of the renamed association, the Brisbane Wool Selling Brokers' Association, shared premises in which their wool was stored and viewed by the buyers before auction. An annexe of the government's Exhibition Building was used for the purpose for many years. The Association negotiated hard with its landlord winning numerous improvements to the site including, better lighting, wider doors to facilitate the movement of bales in and out, and the construction of a rail siding. ${ }^{52}$ The small number of members meant that there was greater involvement in the planning and operation of the market than happened in Sydney or Melbourne where participants built their own wool stores.

\section{PAYOFFS}

Brokers operated in an environment of considerable uncertainty about the future of the industry, which clouded the estimation of pay offs. It was far from certain in the 1890s that Australian sales would replace the consignment system. Dalgety, for instance, consigned more wool than it sold locally until $1901 .{ }^{53}$ Firms had to decide whether to commit to investing in wool stores that might become white elephants in unpropitious circumstances. A severe drought from 1896 until 1902 reduced sheep numbers in New South Wales by 56 per cent, by 68 per cent in Queensland and 23 per cent in Victoria. ${ }^{54}$ Falling wool prices from the late 1880s until the mid-1890s, ${ }^{55}$ added to the woes. Moreover, the Sydney market faced competition from Melbourne and later from Brisbane for New South Wales wool grown near the boundaries of those colonies/states as brokers sought to divert this wool into their sales

\footnotetext{
${ }^{50}$ Waterson, Biographical Register, pp. 105-6.

${ }^{51}$ BWSBA OMA 1767/1 minutes. 20 July 1897, 27 April 1898, and 12 July 1898. JOL.

${ }^{52}$ BWSBA OMA 1767/2 minutes. 14 November 1898, 20 February 1899, 31 July 1899, 9 September 1901 and 28 March 1903, JOL.

${ }^{53}$ Hartwell, Dalgety, chapter 9, p. 11.

${ }^{54}$ Bureau of Agriculture Economics, Statistical Handbook, Table 1, p. 1.

${ }_{55}$ Wool prices halved between 1884 and 1894. Official Year Book of New South Wales 19045, p. 728.
} 
rooms. ${ }^{56}$ Butlin, for instance, estimates that a third of New South Wales wool was shipped into Victoria in the last third of the nineteenth century. ${ }^{57}$

In an environment with high levels of uncertainty about the future of wool broking and with firms making various degrees of commitment to this side of their business we might anticipate that firms, particularly those with pessimistic expectations, would take a short-term view of the pay offs. The uncertainty was augmented by Sydney having a larger number of brokers there than in either Melbourne or Brisbane, with a past history of non-cooperation, who scrambled for market share. Game theory suggests there is a heightened tendency for players to 'cheat' in what they expect to be the last round of the game as they can escape retaliation. ${ }^{58}$ Consequently, Sydney firms would be more likely to 'cheat' than in Melbourne or Brisbane because they anticipated withdrawing from wool broking and/or that the Association would collapse so removing the opportunity to 'cheat' against the agreed charges and arrangements relating to non-price competition.

Sydney-based broking firms discriminated between pay-offs involved from operating a central sale room and from agreements about rents. Payoffs from the operation of a central auction room arose from the increased volume of wool handled in an industry with high fixed costs. While firms 'cheated' on price to such an extent that the formal Association fell into abeyance, the bargains relating to the auction system continued to be honoured in full. ${ }^{59}$ Members continued to operate as a shadow organization by achieving coordination in conducting regular auctions in Sydney, negotiating with buyers' associations, and integrating its sale calendar with those of Brisbane and Melbourne. While Sydney firms were prepared to strike out on their own with regard to price, none attempted to operate independently in selling wool. We would suggest that the impulse to cooperate comes from a calculation of the benefits arising from participating in the central auction system and of the costs of operating

\footnotetext{
${ }^{56}$ For instance, the BWSBA advertised in local newspapers highlighting the government bonus of $£ 1$ per ton of wool sold at the Brisbane auctions. The Queenslander, 24 December 1898, p. 1.

${ }^{57}$ Butlin, Investment in Australian Economic Development, p. 307.

${ }^{58}$ Dixit and Nalebuff, Art of Strategy; Oster, Modern Competitive Analysis, ch. 13.

${ }^{59}$ A new association, the Wool Selling Institute, replaced the SWSBA during 1901. It welcomed the participation of non-member broking firms in the auction rooms provided they were 'prepared to work on the same lines as those we have resolved on...' NZLMA, 110/4/319 Correspondence re new association, Undated. NBAC
} 
outside. It was the buyers rather than the brokers' association who held the whip hand as the buyers in all states forbade their members to deal with non-association brokers. ${ }^{60}$

The Sydney Association placed greater reliance on coercive mechanisms to bond its members yet it was weakened by endemic 'cheating'. We argued above that brokers operating in Sydney through the 1890s and early 1900s faced the greatest amount of uncertainty about the future of this emergent industry and the greatest environmental stress. In this atmosphere, many firms calculated that the pursuit of self-interest favoured independent action with respect to issues of pricing their services and to attracting wool into their stores by using travellers and advertising to attract custom. In the end, the individualistic behaviour had cost everyone dear as margins were competed away. Those firms who recognised what had been lost harboured resentments against those who had abandoned the Association's agreements so lightly while thumbing their noses at their peers. Such behaviours gave rise to continued ill feeling. GM's chairman commented in July 1904 that he was 'rather pleased that they [AMLF] are taking the place of the AMA\&Co as it may lead to better conditions in Sydney' ${ }^{61}$ Old attitudes died hard. Even after the re-formation of the SWSBA, the NZLMA manager complained that 'the [Association] meeting was a discursive one, unduly prolonged by the mock heroics of Mr Lionel Bridge and the spontaneous enthusiasm of Mr Robert Pitt.' Discussion of the draft allowance given to buyers dragged on without resolution, prompting the sarcastic comment that 'the discussion, or rather altercation, on this subject would have been prolonged indefinitely if time had allowed. ${ }^{62}$

For all the residual tensions and bickering mentioned above, the day to day operation of a central auction room in Sydney strengthened the institution over time. The rules and regulations adopted by the Association at the time of its reformation in 1909 were still tougher than those governing the associations in Melbourne and Brisbane. In our view, the growing levels of trust between wool brokers in Sydney mattered more in strengthening that institution than a reframing of the constitution. Individuals representing firms were drawn into regular face to face contact participating in the annual series of wool sales over the previous 17 years. Many of the managers representing firms in the three selling centres held

\footnotetext{
${ }^{60}$ See Victorian Wool Buyers’ Association, Constitution and Rules, 1921, clause 35, UMA, Accession 106/121, Series 22/3/1, Box 44.

${ }^{61}$ GM, Niall to Casey, 12 July 1904, Barnard Papers, Series 2/91, RGC Papers - box 2, London visit 1904, NBAC Deposit ANUA 377.

${ }^{62}$ NZLMA 11/4/340, memo to Mr Graham, 16 March 1910, NBAC.
} 
those posts for decades. ${ }^{63}$ Moreover, members of the Associations regularly travelled 600 miles together by train and ship to attend conferences with brokers in other cities. Friendships were formed and common interests identified that created a pool of social capital that salved remaining frictions. ${ }^{64}$

Changes in behaviour among Sydney brokers was driven by a combination of internal and external pressures. Years of intense competition to protect or gain market share at the expense of their colleagues had driven margins to near competitive levels. Sydney brokers had the example of members of associations in Melbourne and Brisbane generating and enjoying rents. ${ }^{65}$ The pay offs from coordination could be increased by co-operation. Moreover, the associations in other markets were growing concerned that the lower level of charges levied on both growers and particularly buyers in Sydney were used as a bargaining chip to reduce them elsewhere. ${ }^{66}$ Coordination between associations became an imperative to protect the rents being earned by wool brokers across Australia. Over time a number of the major wool brokers were engaged in multiple selling centres. By so doing each gained firsthand experience of the differences in rents being earned at various locations, and this information possibly stimulated the reconstitution of the Sydney Association in 1909.

\section{DISCUSSION AND CONCLUSION}

We have employed the three pillars schema to explore the forces which shaped the establishment and evolution of the institution governing the wool auction system. In doing so, we offer some fresh insights into the institution theory literature. Each of the pillars draws on a distinct social science discipline. Economists and economic historians rely upon the regulatory interpretation, sociologists employ the normative pillar, and cultural anthropologists work within the cultural-cognitive pillar. ${ }^{67}$ Researchers from each discipline might be expected to approach the problem through their own lens. The literature offers few clues as to how the pillars may work together or how their inter-relationship alters over time.

\footnotetext{
${ }^{63}$ For Dalgety see Hartwell [nd], chapter 8, 5-6 \& 10; GM had two Sydney managers, G Maiden and E J E McKenzie, between 1899 and 1914, see entries in Nash, Australasian Joint-Stock Companies ,1899 and1914

${ }^{64}$ Merrett, Morgan and Ville, Industry associations as facilitators, pp. 73-95.

${ }^{65}$ We know of no direct evidence of rates of return from wool broking for any firm in any market during this period.

${ }^{66}$ Australasian Insurance and Banking Record, 20 October 1908, p. 845.

${ }^{67}$ Scott, Institutions and Organizations.
} 
Our study, contextualized by an institution to serve a particular purpose and located in a unique time and location, provides an illustration of how the game plays out. The wool brokers' associations are best understood initially through the use of a regulatory pillar framework. This study of a micro-institution concerns the actions of business people undertaking high stakes investment in a central wool auction. The participants were known to one another through prior dealings, some collaborative such as conducting live stock auctions, while others were competitive, particularly mortgage lending. However, these interactions were unlikely to have had sufficient breadth or time to build strong normative or cultural-cognitive pillars. The participants were predisposed to codify agreements. Local Chambers of Commerce had long been arbiters of commercial practice. Business was conducted in a country using British commercial law that facilitated contract enforcement.

Paradoxically, the strength of a market-based regulatory system gave the participants within the wool brokers' association greater scope for agency. The wider 'rules of the game' as defined by North ${ }^{68}$ encouraged firms to follow their own path confident that their private rights were secure within the scope of the law. Consequently, the broader rules of the game legitimized defection from associational agreements as the pursuit of self interest was permissible. Firms made rational calculations about the benefits and costs from abiding by the rules or cheating. We suggest that localized environmental forces shaped how wool broking firms acted. The severe drought and falling wool prices hit the firms operating in the Sydney market harder than those in Melbourne and Brisbane. Uncertainty was greater amongst Sydney firms because there were more competitors operating there. In these circumstances, many of the Sydney firms felt that their best choice was to cheat on industry agreements with respect to receiving and delivery charges, sales commissions, and non-price competition.

We have argued above that the increasing strength of the institution in Sydney relied on more than a regulatory pillar. Indeed, that pillar was ineffective as 'cheating' was rampant and punishment almost non-existent. Despite this, the Association persisted with much the same form of a highly legalistic and draconian monitoring system in its rules upon re-forming in 1909. The firms in Sydney bonded together for a number of reasons. The end of the drought around 1902 and rising wool prices up to and during World War One brought prosperity to the wool industry in which the brokers shared. More importantly, the repetitive and

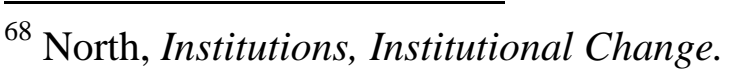


interactive cycle of the auctioning of wool forged a sense of collective identity amongst brokers. Cooperation and squabbles existed side by side. Cooperation coalesced around shared routines in inter-firm communication and negotiation about sale dates, orders of sale, printing catalogues and dealing with buyers, wool scourers, port authorities and the railways commissioners. The emergence of custom and practice strengthen a normative pillar which compensated for the fragility of its regulative cousin. Australia rode to economic recovery and to post-Federation nationhood on the sheep's back. Wool had a special place in the national psyche. It was widely represented in popular culture and media. Leading pastoralists and stud masters were national identities. ${ }^{69}$ The great pastoral companies were national leaders. ${ }^{70}$ Being seen as part of the wool industry gave legitimacy to the firms involved. These developments nourished yet another pillar, the cultural-cognitive.

The rise of normative and cultural-cognitive pillars notwithstanding, the re-formation of the Sydney association relied heavily on the rational calculus of its members. Fierce competition within Sydney for market share had driven profits down. Sydney brokers were aware that members of the Melbourne and Brisbane associations were generating higher margins as a result of their agreements. This knowledge was transmitted to them by Sydney firms which also operated in the other markets. Eventually, Sydney brokers accepted the same levels of prices and restrictions on non-price competition as in the other centres and abided by them. Sydney brokers recognized that they needed to reform their association to interact with the buyers and the other associations. The transfer from consignment to local auction was largely complete. The growth of a mass market required coordination on a national scale. Sydney, the largest market, could not afford to remain aloof. The wheel had turned full circle as Sydney, which had first proposed a unified body, the Associated Brokers of Melbourne and Sydney, in 1895 only to renege, now emerged as its champion. ${ }^{71}$

\footnotetext{
${ }^{69}$ Massy, Australian Merino (Ringwood, Vic.,1990)

${ }^{70}$ Ville, Rural Entrepreneurs; Fleming, Merrett and Ville, Big End of Town.

${ }^{71}$ MWA, 106/121 Minutes, 15 November 1895, 14 January 1896, 21 February 1896, 6 March 1896, 24 April 1896, 21 September 1896, \& 11 December 1896, and Annual Report, 6 March 1896, UMA.
} 
References

Australasian Insurance and Banking Record (1877-1973) (Melbourne VIC).

Bailey, J. D. (1966) A Hundred Years of Pastoral Banking: A History of the Australian

Mercantile Land and Finance Company (Oxford: Clarendon Press).

Barnard, A. (1958) The Australian Wool Market 1840-1900 (Melbourne: Melbourne

University Press on behalf of Australian National University).

Brisbane Stock and Station Agents Association. John Oxley Library, Brisbane. Accession OMA 1767.

Brisbane Wool Selling Brokers Association Minutes. John Oxley Library, Brisbane. Accession OMA 1767.

Bureau of Agriculture Economics, (1949) Statistical Handbook of the Sheep and Wool Industry, (Canberra: the Bureau).

Butlin, N. G. (1962) Australian Domestic Product, Investment and Foreign Borrowing, 1861-1939 (Cambridge: Cambridge University Press).

Butlin, N. G. (1964) Investment in Australian Economic Development 1861-1900

(Cambridge: Cambridge University Press).

Carnevali, F. (2004), 'Crooks, thieves and receivers': transaction costs in nineteenth century Birmingham, Economic History Review 57, 3, 533-550

Carnevali, F. (2011), 'Social capital and trade associations in America, 1870-1914', Economic History Review, 64, 3: 905-28

Dalgety Annual Wool Review (Sydney: Dalgety \& Co).

Dixit, A. K., and Nalebuff, B. J. (2010) The Art of Strategy: A Game Theorist's Guide to Success in Business and Life (New York: W. W. Norton \& Company).

Fleming, G. Merrett, D. T. and Ville, S. (2004) The Big End of Town: Big Business and Corporate Leadership in Twentieth-Century Australia (Melbourne: Cambridge University 
Press).

Franklyn, H. M. (1881) A Glance at Australia in 1880, or, Food from the South

(Melbourne: Victorian Review Publishing Company).

Goldsbrough Mort, Noel Butlin Archives Centre, Canberra. Accession 2.

Gramsie, J. B. (1920) Management and Diseases of Sheep in Australia (Sydney:

Butterworth).

Greenwood, R. Oliver, C., Sahlin, K. and Suddaby, R. (2008) The SAGE Handbook of

Organizational Institutionalism (London: Sage Publications).

Hartwell, R. M. (n.d.) Dalgety typescript. Copy in Dalgety papers in Noel Butlin Archives

Centre, Deposit Z153, Box 96.

Massy, C. (1990) The Australian Merino (Ringwood: Viking O’Neil/Penguin Books

Australia Ltd).

Melbourne Woolbrokers’ Association, University of Melbourne Archives, Melbourne.

Accessions 79 and 106. The latter includes papers from several other related organisations

including National Council of Wool Selling Brokers of Australia and Victorian Woolbuyers Association.

Merrett, D. and Ville, S. (2012) Industry associations and non-competitive behaviour in Australian wool marketing: evidence from the Melbourne Woolbrokers’ Association, 18901939. Business History, 54: 510-528.

Merrett, D. T., Morgan, S. L., and Ville, S. (2008) Industry associations as facilitators of social capital: the establishment and early operations of the Melbourne Woolbrokers' Association. Business History, 50: 781-94.

Nash, R. L. (1899, 1909) Australasian Joint-Stock Companies Year-Book (Melbourne: C. Parker).

New Zealand Loan \& Mercantile Agency. Noel Butlin Archives Centre Accession 110. 
North, D. C. (1990) Institutions, Institutional Change and Economic Performance, $3^{\text {rd }}$ ed.

(Cambridge: Cambridge University Press).

Official Year Book of New South Wales 1904-5 (Sydney: Government of New South Wales).

Oster, S. M. (1994) Modern Competitive Analysis (New York: Oxford University Press).

Popp, A. (2005) '”An indissoluble destiny”': The North Staffordshire Potteries and the

Limits of Regional Trade Associations’, Organization Studies, 21, 12: 1835-49;

Scott, R. W. (2008) Institutions and Organizations: Ideas and Interests, 3rd ed. (London: Sage).

Ville, S. (2000) Rural Entrepreneurs: A History of the Stock and Station Agents in Australia and New Zealand (Melbourne: Cambridge University Press).

Ville, S. (2005) The Relocation of the International Market for Australian Wool. Australian Economic History Review, 45: 73-95.

Ville, S. (2009) 'Making connections': Insights into relationship marketing from the Australasian stock and station agent industry. Enterprise \& Society, 10: 423-48.

Ville, S., and Merrett, D. (2006) Investing in Inter-Organizational Communication: The Melbourne Wool Brokers Association. In: G Boyce, S Macintyre and S Ville. eds. How Organizations Connect. Investing in Communication (Melbourne: Melbourne University Press), pp. 171-79.

Waterson, D. B. (1972) A Biographical Register of the Queensland Parliament 1860-1929

(Canberra: Australian National University Press).

Were’s Statistical Service (various years) (Melbourne). 
Table 1: Institution agreements, monitoring processes and penalties, c.1909

\begin{tabular}{|c|c|c|c|}
\hline & Melbourne & Sydney & Brisbane \\
\hline Governance & $\begin{array}{l}\text { All members on } \\
\text { committee }\end{array}$ & $\begin{array}{l}\text { All members on } \\
\text { committee }\end{array}$ & $\begin{array}{l}\text { All members on } \\
\text { committee }\end{array}$ \\
\hline Votes per member & One & $\begin{array}{l}\text { Weighted by } \\
\text { sales }\end{array}$ & $\begin{array}{l}\text { Weighted by } \\
\text { sales }\end{array}$ \\
\hline Chair elected & At AGM & No & At AGM \\
\hline Majority required & Simple majority & $\begin{array}{l}\text { Complex } \\
\text { schedule }\end{array}$ & $\begin{array}{l}\text { Complex } \\
\text { schedule }\end{array}$ \\
\hline Payment for committee work & No & Yes & Fined for lateness \\
\hline Warehouse procedures & $\begin{array}{l}\text { Weighing } \\
\text { in/weighing out; } \\
\text { sampling; } \\
\text { payment/collection }\end{array}$ & $\begin{array}{l}\text { Similar } \\
\text { provisions }\end{array}$ & $\begin{array}{l}\text { Similar } \\
\text { provisions }\end{array}$ \\
\hline $\begin{array}{l}\text { Receiving/commission/delivery } \\
\text { fee }\end{array}$ & $\begin{array}{l}\text { Agree to impose } \\
\text { Change over time }\end{array}$ & $\begin{array}{l}\text { Agree to impose } \\
\text { Change over } \\
\text { time }\end{array}$ & $\begin{array}{l}\text { Agree to impose } \\
\text { Change over time }\end{array}$ \\
\hline Rebates & Agree to limit & Agree to limit & Agree to limit \\
\hline Travellers & $\begin{array}{l}\text { Agree to limit } \\
\text { poaching by rivals }\end{array}$ & $\begin{array}{l}\text { Agree to limit } \\
\text { poaching by } \\
\text { rivals } \\
\text { Limit on } \\
\text { number }\end{array}$ & $\begin{array}{l}\text { Agree to limit } \\
\text { poaching by } \\
\text { rivals }\end{array}$ \\
\hline Advertising & Agree to forgo & Agree to forgo & Agree to forgo \\
\hline Monitoring & $\begin{array}{l}\text { By members but } \\
\text { reduce vexatious } \\
\text { claims }\end{array}$ & $\begin{array}{l}\text { By members } \\
\text { mandatory }\end{array}$ & $\begin{array}{l}\text { Duty of members } \\
\text { to report breach }\end{array}$ \\
\hline Disciplinary action taken by & Vote by members & $\begin{array}{l}\text { Two step } \\
\text { process: Serious } \\
\text { breach dealt } \\
\text { with by external } \\
\text { arbitrator }\end{array}$ & $\begin{array}{l}\text { Vote by } \\
\text { members, } \\
\text { recourse to } \\
\text { external advisers } \\
\text { in serious matters }\end{array}$ \\
\hline
\end{tabular}




\begin{tabular}{|l|l|l|l|}
\hline Breaches & Infrequent \& minor & $\begin{array}{l}\text { Frequent \& } \\
\text { major }\end{array}$ & $\begin{array}{l}\text { Infrequent \& } \\
\text { minor }\end{array}$ \\
\hline Penalties & Fines \& expulsion & $\begin{array}{l}\text { Fines \& } \\
\text { expulsion }\end{array}$ & $\begin{array}{l}\text { Fines \& } \\
\text { expulsion }\end{array}$ \\
\hline Joining fee/Bond & $\begin{array}{l}£ 100 \text { and } £ 500 \\
\text { 'contribution' }\end{array}$ & $£ 500$ & $\begin{array}{l}£ 100 \text { and } £ 100 \\
\text { 'contribution’ }\end{array}$ \\
\hline Term of Agreement & Open ended & $\begin{array}{l}\text { Three to five } \\
\text { years }\end{array}$ & Open ended \\
\hline
\end{tabular}

Source: NZLMA, Sydney Wool and Produce; NZLMA , Rules and Regulations, NBAC Deposit 110/4/340; University of Melbourne Archives, Accession 196/121/, and Brisbane Wool Selling Brokers Association, Rules and Regulations, October 1898, November 1900 and August 1909, JOL, OMA/27/1. 
Table 2: Original members of associations in Sydney, Melbourne and Brisbane

\begin{tabular}{|l|l|l|}
\hline Sydney 1889 & Melbourne 1893 & Brisbane 1898 \\
\hline $\begin{array}{l}\text { Australasian Mortgage \& } \\
\text { Agency [1863] [F] }\end{array}$ & $\begin{array}{l}\text { Australasian Mortgage \& } \\
\text { Agency [F] }\end{array}$ & \\
\hline Dalgety [1884] [F] & Dalgety [F] & Dalgety [F] \\
\hline NZLMA [1865] [F] & NZLMA [F] & NZLMA [F] \\
\hline $\begin{array}{l}\text { Goldsbrough Mort [1881, } \\
\text { absorb Mort 1888] [F] }\end{array}$ & Goldsbrough Mort [F] & \\
\hline $\begin{array}{l}\text { Harrison, Jones \& Devlin } \\
\text { [1882] }\end{array}$ & $\begin{array}{l}\text { Younghusband \& Co } \\
\text { [1889] }\end{array}$ & Moreheads [1899] \\
\hline $\begin{array}{l}\text { Hill, Clark [1909] } \\
\text { J H Geddes - absorbed by } \\
\text { PSA 1891 }\end{array}$ & & Thomas Noyes \\
\hline $\begin{array}{l}\text { John Bridge [1897] } \\
\text { Pastoral Finance } \\
\text { Association [1891] }\end{array}$ & & Fenwick [1864] \\
\hline $\begin{array}{l}\text { Winchcombe, Carson } \\
\text { [1889] }\end{array}$ & & \\
\hline Wyly, Trenchard & & \\
\hline
\end{tabular}

Notes: Date of company registration is denoted by [1863]; otherwise a partnership. [F] denotes financier.

Source: As for Table 1 and Nash, Australasian Joint-Stock Companies, various. 
Table 3: New entrants to associations before 1909

\begin{tabular}{|l|l|l|}
\hline Sydney & Melbourne & Brisbane \\
\hline $\begin{array}{l}\text { Pitt, Son \& Badgery [1888] } \\
\text { (1898) }\end{array}$ & $\begin{array}{l}\text { Australian Estates acquire } \\
\text { UMA in 1899 [F] }\end{array}$ & $\begin{array}{l}\text { Australian Estates acquire } \\
\text { UMA in 1899 [F] }\end{array}$ \\
\hline Schute Bell [1901] (1909) & $\begin{array}{l}\text { Victorian Farmers Loan } \\
(1894-97)\end{array}$ & $\begin{array}{l}\text { McTaggart Bros [1886] } \\
\text { (1899) }\end{array}$ \\
\hline & $\begin{array}{l}\text { National Wool Trading } \\
\text { Co. (1894-97) }\end{array}$ & Sturmfels [1907] (c1907) \\
\hline $\begin{array}{l}\text { Co-operative Wool \& } \\
\text { Produce (1898-1901) }\end{array}$ & $\begin{array}{l}\text { R. Goldsbrough Row } \\
(1900)\end{array}$ & $\begin{array}{l}\text { AML\&F absorbs AM\&A } \\
\text { in 1904 [F] }\end{array}$ \\
\hline
\end{tabular}

Notes: Date of establishment as a company is denoted by [1888] and date of joining an association is shown by (1898). A range of dates is given when year of first membership is unknown. [F] denotes financier.

Source: As for Table 1 and Nash, Australasian Joint-Stock Companies, various. 